\title{
Cell-Mediated and Humoral Immune Responses in the Sea-Star Asterias Rubens (Echinoderm): Notion of Invertebrate Primitive Antibody
}

\author{
Leclerc $\mathrm{M}^{\star}$
}

556 rue Isabelle Romée, 45640 Sandillon, France

*Corresponding author: Leclerc M, 556 rue Isabelle Romée, 45640 Sandillon, France, E-mail: mleclerc45@gmail. com

Citation: Leclerc M (2015) Cell-Mediated and Humoral Immune Responses in the Sea-Star Asterias Rubens (Echinoderm): Notion of Invertebrate Primitive Antibody. SAJ Biotechnol 2: 102. doi: 10.18875/23756713.1.302

Article history: Received: 12 December 2014, Accepted: 22 January 2015, Published: 26 January 2015

\section{Abstract}

The axial organ is considered as ancestral lymphoïd organ. It contains T-like and B-like sea star lymphocytes and Phagocytes. It plays a fundamental rôle in the sea star cell-mediated immune responses and humoral immune ones.

Keywords: Invertebrate; Immunogenesis; Invertebrate primitive antibody; Sea-star axial organ; Echinoderma

\section{Cell-mediated Immune responses}

\section{Introduction}

In Vertebrates, immunity is characterized by physiological mechanisms mediated by variuos types of cells and various soluble proteins, whose complex interplay results in a defence response which is specific and anamnesic for each particular immunogen (antigen) and which is greatly amplified in the presence of such antigen.

B-like and T-like lymphocytes, phagocytes and other cells of the reticuloendothelial system, leukines secreted by these cells, complement and humoral antibodies have been studied in great detail in vertebrates, especially in mouse and man, but little information is available on the presence(or absence) of them, especially humoral antibodies, in invertebrates.

Although it is largely admitted that the origin of the immune response resides among invertebrates, no definite evidence exists concerning the phylogeny of such response or the evolutionary homologies between the various components of the immune system and the components of the «immune system » of invertebrates.

The works of Cooper [1], have first demonstrated the existence of cell-mediated immune reactions in annelids. It has also been shown that tunicates can recognize and react to alloantigenic determinants, and Hildeman et al [2] have presented strong evidence of highly discriminating immunocompetence in echinoderms.

In 1966, Millott [3] proposed that the axial organ of the sea urchin was implicated in defence mechanisms. Cells present in this organ are morphologically very similar to vertebrate lymphocytes, and this similarity prompted the idea that the axial organ could be an ancestral lymphoïd organ [4].

A great number of experiments performed in our laboratory in recent years have confirmed this hypothesis, showing that the axial organ cells of the sea-star are able to mount a cellular and humoral response having many of the characteristics of the vertebrate immune system.

The invertebrates consist of a variety of phyla whose exact evolutionary relationships and genealogy are difficult to assess:

\section{Echinoderma}

The position of the echinoderms, in particular, has been a matter of doubt and controversy in the studies of the vertebrate ancestors. Embryological, anatomical and biochemical evidence seem now to indicate that the first one is wrong: echinoderms, as proposed 
Kampmeier [5], are more likely to have been the ancestors of the invertebrates than the annelids. An essential point appears to be the fact that echinoderms are deuterostomia, like the vertebrates, while annelids are protostomia, like arthropods and mollusks.

In the ontogeny of protostomia, the «blastopore » becomes the mouth; in the deuterostomia, on the contrary, the anus arises from the blastopore, the mouth being a new acquisition. It must also be remarked that although, in the phylum Echinodermata, the adult animal has a radial symetry, the larva is bilateral.

\section{The sea-star Asterias rubens}

Sea-stars belong to the class Asteroidea of the phylum Echinodermata. They are marine animals, also named starfishes. They have a pentaradiate structure with a calcareous endoskeleton. The Asteroidea do not possess a definite head or brain but an oral and an aboral face. On the aboral face, the madreporite takes place as a circular grooved plate, situated in the interradius CD or Carpenter's system. Just under the madreporic plate is the axial complex. The axial organ lies along the stone canal [6]. The structure of the axial organ is glandular, spongy and crossed by connective tissue. Many follicles of heterogeneous size with clear zones are lined by cellular cords. The various types of cells present in the axial organ have been studied in our laboratory, by optical and electron microscopy (S.E.M and T.E.M). Essentially two types of cells are found:
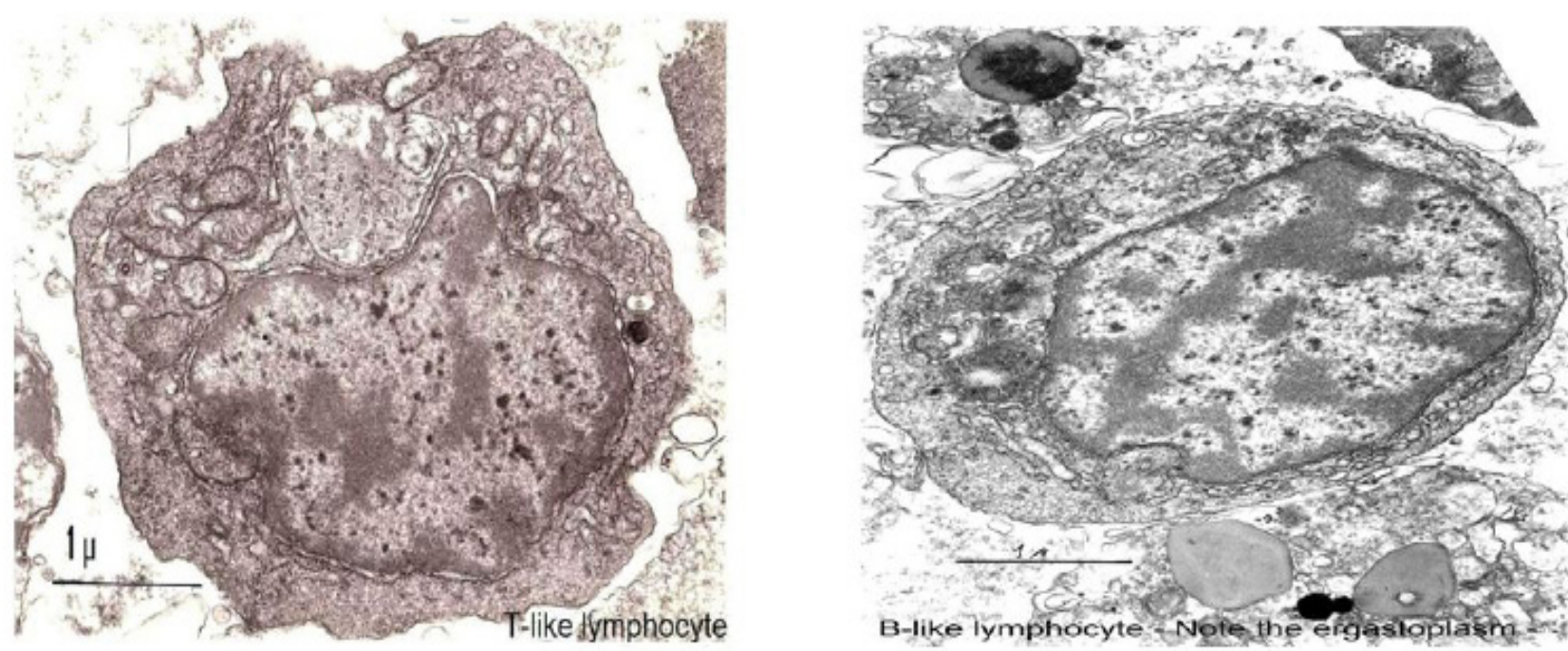

Figure 1 and 2: Cells which morphologically resemble mammal lymphocytes

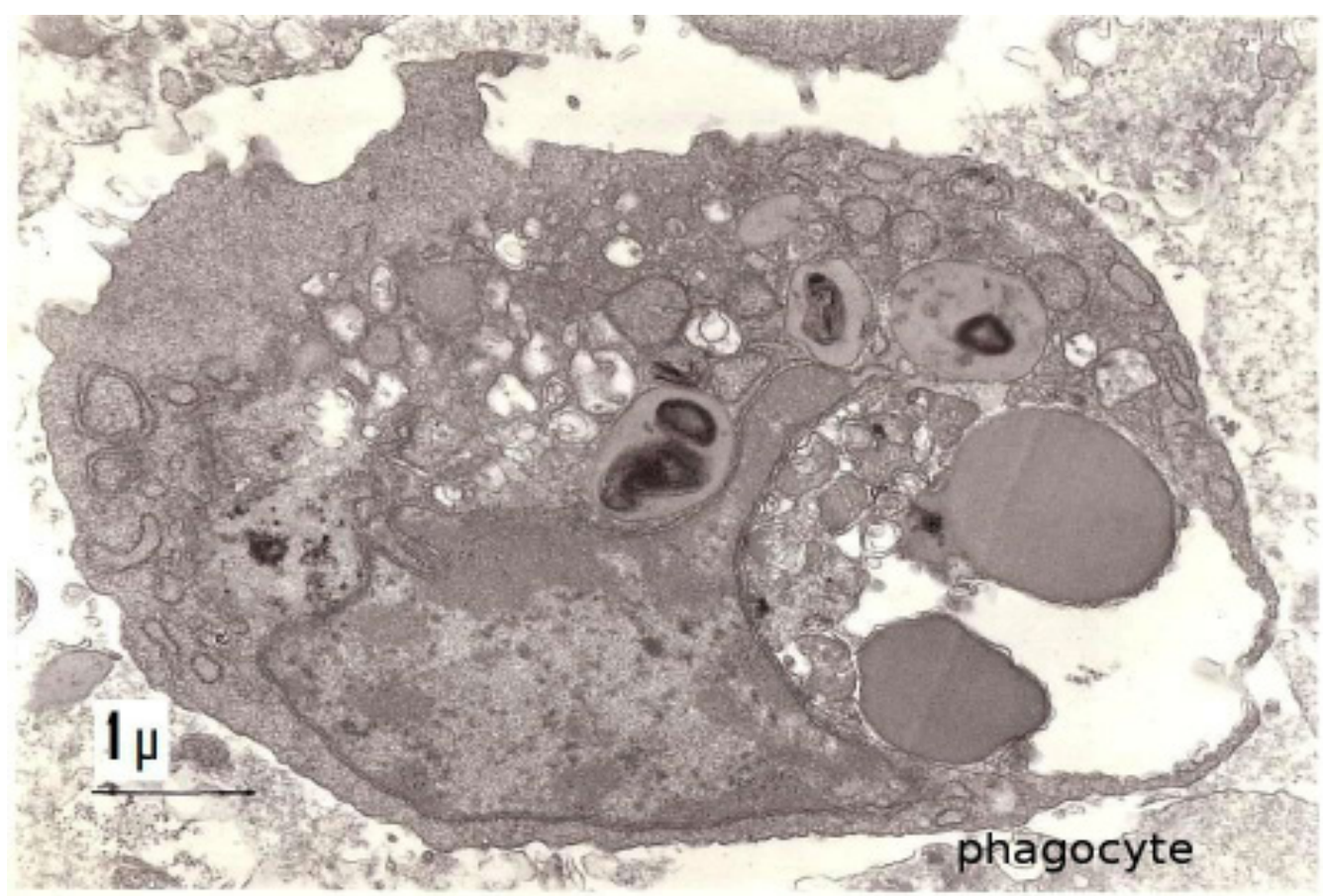

Figure 3: Cells which are phagocytes 


\section{Properties of the axial organ cells}

\section{Obtention and separation of cells}

Axial organs were removed, pooled, washed with sterile buffer and teased. The cells were finally filtered through a sterile fine-mesh nylon cloth (pore diameter: $20 \mu \mathrm{m}$ ). The buffer used throughout contained a high concentration of $\mathrm{NaCl}$, similar to that of the sea water.

The total population could be separated into two subpopulations according to the method of Julius et al [7]: Adherent cells, represented about $20 \%$ of the whole axial organ population, and non-adherent cells $80 \%$. The percentage of adherent cells was enhanced after antigenic stimulation and grew up to $35 \%$ in some cases.

\section{Morphology}

Adherent and non adherent cells were studied by electron microscopy after fixing in $2 \%$ glutaraldehyde in cacodylate buffer 0.4 $\mathrm{M}, 3 \mathrm{mM}$. Ultrastructural cytochemistry was performed to detect endogenous peroxidase by the well-known diaminobenzidine method Results were summarized in the work of Anteunis, Leclerc et al [8].

Non-adherent population: Cellular types found in the non-adherent population resembled the lymphocytes and mononuclear phagocytes of the vertebrates. Lymphocyte cells (Figure 1 and 2) were small, average diameter $4 \mu \mathrm{m}$, and had a high nucleocytoplasmic ratio. The second cellular type observed was a phagocytic cell whose diameter was 7-8 $\mu \mathrm{m}$ (Figure 3). Its nucleus wax excentric and could have two aspects: in some cells, the diffuse chromatin was predominant, while others were principally composed of condensed chromatin. The cytochemical DAB procedure for visualization of endogenous peroxidase showed a negative reaction in the lymphocyte-like cells and a positive staining in some phagocytic cells. This reaction was located in the endoplasmic reticulum and in the phagosomes. The experimental conditions used did not permit detection of any positivity in the perinuclear space or in the Golgi apparatus.

\section{Adherent population}

Two types of cells were also observed in the adherent population: One type resembled lymphoplasmocytes. These cells had a nucleocytoplasmatic ratio lower than that of the non-adherent cells and a more highly developed vacuolar system, i.e. Smoothand rough-surfaced endoplasmic reticulum in variable quantities and large multivesicular bodies. These cells represented $20 \%$ of the adherent population and 5-10\% of the whole cell population. The diameter of these cells was also greater than that of the non-adherent cells, namely 5 to $6 \mu \mathrm{m}$. Within this cellular type, some were characterized by substantial development of the rough endoplasmic reticulum and by the presence of lipids and dense bodies of irregular form and heterogeneous density. The other type found was a phagocytic cell similar to that found in the non-adherent population. These cells also had a positive endogenous peroxidase reaction localized in the endoplasmic reticulum and in the phagosomes.

\section{Effect of mitogens}

To test the action of mitogens, cell cultures were performed [7] The mitogens tested were PWM (pokeweed), ConA (Concavalin A), LPS (Lipopoysaccharide) Limulin, PHA (phytohaemagglutinin) (Sigma products) Nocardia opaca delipidated. Different axial organ cellular populations (total, adherent and non-adherent to nylon wool) were cultured for 24,48 , and $72 \mathrm{~h}$ in the presence of various concentrations of these mitogens [9] and the stimulation indexes were calculated. A summary of the results obtained, is presented in Table 1, where it can be seen that non-adherent cells where stimulated by PWM, ConA, Limulin and PHA, but not by LPS and Nocardia opaca delipidated. Adherent cells were stimulated by LPS and Nocardia opaca delipidated [9]. When the total population was tested, considerable stimulation was observed only in the presence of PWM, a weak stimulation was observed in the presence only of foetal calf serum. In general stimulation was greatest after $48 \mathrm{~h}$ of contact and then diminished. A dose-effect was also observed with high concentations of mitogens producing less stimulation. The conclusion that can be drawn from these experiments is that non-adherent and adherent cellular subpopulations, respectively, were stimulated by the same mitogens which stimulate mammal T and B lymphocytes. This analogy is further reinforced by the fact that the procedure employed to separate adherent from non-adherent cells is identical to that used to separate B from T lymphocytes.

\begin{tabular}{|c|c|c|c|}
\hline Mitogen & Total population & Adherent cells & Non-adherent cells \\
\hline PWM & + & - & + \\
\hline ConA & - & - & + \\
\hline Limulin & - & - & + \\
\hline PHA & - & + & + \\
\hline LPS & - & + & - \\
\hline Nocardia-opaca & - & - & + \\
\hline
\end{tabular}

Table 1: Effect of various mitogens on axial organ cells 


\section{Agglutination by Lectins}

It was found that axial organ cells were selectively agglutinated by lectins [10]. This property allowed fractionation of the cells into two subpopulations. Soybean agglutinin (SBA) and wheat germ agglutinin (WGA) agglutinated about $10 \%$ of the cells. In contrast, Con A agglutinated a very large number of cells. The agglutinated cells could be dissociated with appropriate concentrations of sugar specific for the lectin and they were viable after dissociation by use of trypan blue.

\section{Lymphokine substances}

The method of Leiper and Solomon [11] was used, with some modifications. Cells were separated by nylon wool and were cultured for $24 \mathrm{~h}$ at $10{ }^{\circ} \mathrm{C}$ in the presence of PWM-coated Sepharose beads. Supernatants from these cultures were centrifuged to eliminate beads and debris, sterilized by membrane filtration (0.22- $\mu$ m Millipore) and concentrated 5- or 10-fold with an ultrafiltration device (Amicon) fitted with « PM-10 Diaflo» membranes. Supernatant controls were obtained from cells cultured with non-coated beads, from cells cultured alone and from beads cultured alone.

The supernatants were added to cultures of total axial organ cells which had been started $24 \mathrm{~h}$ before, and $24 \mathrm{~h}$ later, the cells were harvested and mitogenic stimulation was evaluated by measuring tritiated-H-methyl- thymidine incorporation. It was found that the the supernatant from the non-adherent cells cultured in the presence of PWM beads stimulated the total axial organ cells. No stimulation was observed in the various controls. This result indicates that non-adherent cells produce a lymphokine mediator which is able to stimulate the total axial organ cells. The active substance was inactivated by trypsin and chemotrypsin, or by heating for $1 \mathrm{~h}$ at $70{ }^{\circ} \mathrm{C}$, but it resisted at $56^{\circ} \mathrm{C}[12]$. In 1997, cytokines and cytokine-receptors were discovered indirectly by the use of Cytofluorometry [13].

\section{Immune reactions induced by axial organ cells}

Attempts were made to demonstrate the capability of axial organ cells to induce cellular immune reactions in various systems currently employed with vertebrate cells.

\section{Angiogenesis}

It was found that angiogenesis was induced when irradiated mice were injected subcutaneously with a suspension of axial organ cells. The technique employed was that described by Sidky and Auerbach [14] who presented it as a graft-versus-host reaction. A study of the effector cells, inducing this phenomenon showed that they were non-adherent to nylon wool, agglutinated by ConA and non-agglutinated by WGA or SBA. In this respect, the effector cells resembled mammal T lymphocytes.

\section{Splenomegaly}

Injection of axial organ cells into 16-day chicken embryos induced significant splenomegaly. Appropriate controls using killed cells, sea star ovocytes or sea star brachial digestive cells were all negative $[15,16]$.

\section{Mixed lymphocyte reaction}

The mixed lymphocyte reaction between axial organ cells from A.rubens and another sea star, Marthasterias glacialis, gave a positive response at the fifth day of culture [17].

\section{Cytotoxicity toward tumour cells}

Axial organ cells, had spontaneous cytotoxicity toward malignant mouse target cells (MBL2 cells), an induced cytotoxicity toward mouse SP2 cells [18]. That study was performed according to the method of Brunner et al [19].

\section{Humoral Immune reactions induced by axial organ cells}

In the first study (Leclerc, 1973), it was shown that the Asterina gibbosa axial organ cells, previously injected with horseradish peroxydase(HRP) were able to react specifically with the same enzyme. This observation was made by T.E.M, using an immunocytochemical technique. A similar result was later observed with the Asterid: Asterias rubens. Since a variety of antigens, were injected in the coelomic cavity, near the axial organ of Asterids, such as: E.coli alkaline phosphatase, bovine serum albumin, rat IgG, human lambda Bence-Jones protein, myoglobin, and more recently, the haptens: TNP and FITC coupled to polyacrylamide beads. Results were summarized in 2012 [20]. We identified an invertebrate primitive antibody, characteristics of which were: specificity and structure(2 Ig sites) after its(sea star) immunization to HRP and genomic research [21]: The gene showed a specific immune response to the enzyme HRP after its insertion in an Escherichia coli plasmid [22]. Other vectors such as pCMV-Tag 3B, are studied.

Our data contributes to knowledge the molecular and genetic bases of non-self recognition by invertebrates which allow further comprehension of the evolution of MHC antigens and immunoglobulins. Notion of primitive invertebrate Antibody is explored. 


\section{Conclusions}

The general idea that emerges from the experiments reported in the present review is that Echinoderma, as exemplified by the sea star: Asterias rubens, possess an ancestral lymphoïd organ: the axial organ. It appears that all the elements necessary to immune responses (phagocytic cells, T-like lymphocytes, B-like lymphocytes, NK cells) are present in this organ which initiates: cellmediated immune responses, the primitive antibody, the lymphokines of the sea star.

\section{References}

1. Cooper EL (1969) Specific tissue graft rejection in earthworms. Science 166: 1414-5.

2. Hildemann WH, Dix TG (1972) Transplantation reactions of tropical Australian echinoderms. Transplant 14: 624-33.

3. Millott N (1966) A Possible Function for the Axial Organ of Echinoids. Nature 209: 549-96.

4. Leclerc M, Brillouet C, Luquet G (1980) The starfish axial organ: an ancestral lymphoid organ. Dev Comp Immunol 4: 605-15.

5. Kampmeier OF (1969) Evolution and comparative morphology of the lymphatic system. Charles C Thomas Springfield: 72.

6. Julius MH, Simpson E, Herzenberg LA (1973) A rapid method for the isolation of functional thymus-derived murine lymphocytes. Eur J Immunol 3: 645-9.

7. Brillouet C, Leclerc M, Panijel J, Binaghi R (1981) In vitro effect of various mitogens on starfish (Asterias rubens) axial organ cells. Cell Immunol 57: 136-44.

8. Anteunis A, Leclerc M, Vial M, Brillouet C, Luquet G, et al. (1985) Immunocompetent cells in the starfish Asterias rubens. An ultrastructural study. Cell Biol Int Rep 9: 663-70.

9. Leclerc M, Bahmaoud T, Brillouet C, Tlaskalová-Hogenová H, Petit JF, et al. (1988) Stimulation of sea star Asterias rubens axial organ B-like cells by Nocardia-delipidated cell mitogen and derived fractions. Folia Biol (Praha) 34: 182-91.

10. Redziniak G, Leclerc M, Panijel J, Monsigny M (1978) Separation of two different populations of axial organ cells of Asterias rubens by the use of lectins. Biochimie 60: 525-7.

11. Leiper JB, Solomon JB (1977) Ontogeny of mitogenic responsiveness to PHA and sheep erythrocytes and lymphokine production in foetal guinea-pigs. Immunology 32: 215-26.

12. Leclerc M, Brillouet C, Luquet G, Agogue P, Binaghi RA (1981) Properties of cell subpopulations of starfish axial organ: in vitro effect of pokeweed mitogen and evidence of lymphokine-like substances. Scand J Immunol 14: 281-4.

13. Legac E, Vaugier GL, Bousquet F, Bajelan M, Leclerc M (1996) Primitive cytokines and cytokine receptors in invertebrates: the sea star Asterias rubens as a model of study. Scand J Immunol 44: 375-80.

14. Sidky YA, Auerbach R (1975) Lymphocyte-induced angiogenesis: a quantitative and sensitive assay of the graft-vs.-host reaction. J Exp Med 141: 1084-100.

15. Leclerc M, Redziniak G, Panijel J, El Lababidi M (1977) Reactions induced in vertebrates by invertebrate cell suspensions. I/Specific effects of sea star axial organ cells injection. Dev Comp Immunol 1: 299-310.

16. Leclerc M, Redziniak G, Panijel J, El Lababidi M (1977) Reactions induced in vertebrates by invertebrate cell suspensions. II/Non adherent axial organ cells as effector cells. Dev Comp Immunol 1: 311-20.

17. Luquet G, Brillouet C, Leclerc M (1984) MLR-like reaction between axial organ cells from asterids. Immunol Lett 7: 235-8.

18. Luquet G, Leclerc M (1983) Spontaneous and induced cytotoxicity of axial organ cells from Asterias rubens (Asterid--echinoderm). Immunol Lett 6: 339-42.

19. Brunner KT, Mauel J, Cerottini JC, Chapuis B (1968) Quantitative assay of the lytic action of immune lymphoid cells on 51-Cr-labelled allogeneic target cells in vitro; inhibition by isoantibody and by drugs. Immunology 14: 181-96.

20. Leclerc M (2012) Humoral immune responses to various antigens in the asterids: a.gibbosa and A.Rubens. Amer.J.Immun 8: 196-9.

21. Vincenta N, Osterasa M, Ottena P, Leclercb M (2014) A new gene in A. rubens: A sea star Ig kappa gene. Meta Gene 2: 320-2.

22. Leclerc M, Otten P (2014) Immune Properties Corroborated By A. Rubens Sea Star Igkappa. SAJ Biotechnol 1: 1-3. 